\title{
PROSES DESORPSI LOGAM BERAT PADA SEDIMEN SUNGAI DAERAH MURIA DENGAN PELARUT ASAM
}

\author{
Supriyanto C., Muzakky \\ Pusat Teknologi Akselerator dan Proses Bahan BATAN \\ Jl. Babarsari Kotak Pos 6101 ykbb, Yogyakarta 55281
}

Diterima 22 Desember 2009, diterima dalam bentuk perbaikan 19 Januari 2010, disetujui 20 Januari 2010

\begin{abstract}
ABSTRAK
PROSES DESORPSI LOGAM BERAT PADA SEDIMEN SUNGAI DAERAH MURIA DENGAN PELARUT ASAM. Telah dilakukan proses desorpsi logam berat $\mathrm{Cr}$, $\mathrm{Cu}$, dan Fe pada sedimen sungai daerah Muria menggunakan pelarut asam. Proses desorpsi dilakukan pada sedimen sungai Kancilan, Balong, Suru, Dombang, dan Wareng dengan cara ekstraksi padat-cair menggunakan pelarut asam $\mathrm{HF}+\mathrm{HNO}_{3} ; \mathrm{HNO}_{3} 4 \mathrm{~N}+\mathrm{HCl} 0,7 \mathrm{~N}$, dan $\mathrm{HCl} 0,5 \mathrm{~N}$, pada suhu $150{ }^{\circ} \mathrm{C}$, selama waktu $4 \mathrm{jam}$. Hasil proses desorpsi ditentukan menggunakan metode nyala spektrometri serapan atom pada kondisi optimum masing-masing unsur. Pada proses desorpsi menggunakan pelarut asam HF $40 \%+\mathrm{HNO}_{3} 65 \%$, diperoleh kadar $\mathrm{Cr}$ dan Fe tertinggi masing-masing pada sedimen sungai Balong dengan $\mathrm{Cr}$ terdesorpsi 173,56 $\mu \mathrm{g} / \mathrm{g}$ dan Fe 251,88 mg/g. Pada proses desorpsi Cu diperoleh kadar Cu tertinggi 96,24 $\mu \mathrm{g} / \mathrm{g}$ pada sedimen sungai Suru menggunakan pelarut asam $\mathrm{HNO}_{3} 4,0 \mathrm{~N}+\mathrm{HCl} 0,7$. Validasi metode uji dilakukan dengan SRM GBW 1645, dan GBW 07313 dengan perolehan kadar Cr, Cu dan Fe berada dalam sertifikat SRM.
\end{abstract}

Kata kunci : proses desorpsi, logam berat, sedimen sungai, metode AAS.

\begin{abstract}
DESORPTION PROCESS OF HEAVY METAL AT RIVER SEDIMENT IN MURIA AREA USING ACID SOLVENT. A desorption process of heavy metal such as $\mathrm{Cr}$, $\mathrm{Cu}$, and Fe element at river sediment in Muria area has been performed by using acid solvent. The activity was conducted on the river sediments of Kancilan, Balong, Suru, Dombang, and Wareng using liquid-solid extraction method with $\mathrm{HF}+\mathrm{HNO}_{3} ; \mathrm{HNO}_{3} 4 \mathrm{~N}+\mathrm{HCl} 0.7 \mathrm{~N}$, and $\mathrm{HCl} 0.5 \mathrm{~N}$ as acid solvent at $150^{\circ} \mathrm{C}$ for 4 hours. The desorption process was determinated with flame atomic absorption spectrometry method at the optimum condition of each element. At the desorption process, the highest content obtained were $\mathrm{Cr} 173.56 \mu \mathrm{g} / \mathrm{g}$, and $\mathrm{Fe} 251.88 \mathrm{\mu g} / \mathrm{g}$ for Balong river sediment, that were treated by using acid solvent of $\mathrm{HF} 40 \%+\mathrm{HNO}_{3} 65 \%$. While at the desorption process of $\mathrm{Cu}$ the higher content obtained was $96.24 \mu \mathrm{g} / \mathrm{g}$ for Suru river sediment that is treated by using $\mathrm{HNO}_{3} 4.0 \mathrm{~N}+\mathrm{HCl} 0.7$ as acid solvent. The validation method was done by using SRM GBW 1645, and GBW 07313 IAEA certified materials. The result show that obtained $\mathrm{Cr}, \mathrm{Cu}$, and $\mathrm{Fe}$ elements were specified in the certificated legend.
\end{abstract}

Key words : desorption process, heavy metal, river sediment, AAS method.

\section{PENDAHULUAN}

Kegiatan Analisis Mengenai Dampak Lingkungan (AMDAL) di lingkungan Semenanjung Muria merupakan Dersyaratan penting untuk dapat dibangunnya PLTN di Indonesia yang telah dicanangkan sejak 1977. Salah satu aktivitas AMDAL yang perlu dilakukan adalah untuk memperoleh data sebaran logam berat terhadap sungai-sungai di sekitar perairan Muria. Walaupun pembangunan PLTN tersebut belum dimulai aktivitasnya, tetapi data-data AMDAL tersebut setelah lima tahun harus diperbaharui sebagai data "background level" 5 tahunan. Kegiatan rutin ini penting karena untuk mengevaluasi pencemaran khususnya pencemaran akibat logam berat di Daerah Aliran Sungai (DAS) sekitar Muria. Akibat dari kegiatan AMDAL ini diharapkan gejolak peningkatan atau penurunan logam berat di sekitar Daerah Aliran Sungai (DAS) Muria dapat lebih awal diketahui, sehingga pengambil keputusan PEMDA setempat dapat mencegah atau melokalisir.

Kegiatan AMDAL salah satunya adalah monitoring yang berguna untuk menentukan konsentrasi kontaminan awal atau rona awal dari polutan berbahaya di suatu wilayah tertentu ("background area") ${ }^{(1)}$. Menurut Ziwart dan Trivedi ${ }^{(2)}$, dampak dari kegiatan pemantauan diharapkan dapat melakukan identifikasi ancaman- 
ancaman yang potensial terhadap kesehatan manusia dan ekosistim alam (ekotoksikologi). Hasil data yang didapat selanjutnya dilakukan evaluasi untuk pemenuhan terhadap beberapa standar pemerintah (PP No 7 1999) ataupun beberapa standar internasional seperti WHO, IAEA, ISD dll. Keluaran kegiatan pemantauan dapat dipakai oleh pengambil keputusan (Pemerintah), untuk diinformasikan kepada masyarakat tentang kualitas lingkungan sungai selajutnya dapat dikembangkan unuk membangkitkan kepedulian masyarakat akan isu-isu lingkungan.

Kegiatan pemantauan dipilih daerah atau area dengan radius $2 \mathrm{~km}$ hingga $5 \mathrm{~km}$ dari calon tempat dibangunnya PLTN pertama di Indonesia yaitu Ujung Lemahabang. Daerah dengan luasan radius $2 \mathrm{~km}$ hingga 5 $\mathrm{km}$ tersebut yang diperkirakan sebagai sumber utama penyebab pencemaran selain PLTN sendiri adalah sungai-sungai yang melewati di daerah tersebut. Sungai-sungai yang terdapat pada $2 \mathrm{~km}$ hingga $5 \mathrm{~km}$ seperti Sungai Kancilan, Sungai Balong, Sungai Suru, Sungai Dombang dan Sungai Wareng. Sungai-sungai tersebut diperkirakan membawa polutan ion logam yang berasal dari pelapukan batuan dan mineral, limbah pertanian (pestisida dan pupuk), industri kayu dan limbah domestik yang dibawa dari daerah yang lebih luas radiusnya. Pada daerah radius $2 \mathrm{~km}$ hingga $5 \mathrm{~km}$ dimana muara kelima sungai-sungai tersebut berada, diperkirakan akan terakumulasi pencemar ion logam dari tahun ketahun akan terus bertambah. Jadi dengan mengambil sampel dari ke lima sungai-sungai tersebut untuk ditentukan rona awalnya diharapkan telah memenuhi syarat pemantauan sesuai dengan persyaratan oleh Canter, $1996^{(3)}$.

Untuk melakukan pemantauan sesuai persyaratan, diperlukan data-data kandungan unsur yang ada dalam ke lima sedimen sungai. Salah satu metoda yang dapat digunakan adalah metoda nyala spektrometri serapan atom (SSA). Pada metoda SSA, cuplikan sedimen diubah menjadi bentuk larutan melalui proses ekstraksi padatcair. Menurut Murray, C.N. and Murray, L..$^{(4)}$ desorpsi yang terjadi pada ekstraksi padat-cair merupakan peristiwa keluarnya analit yang terkandung di dalam "bulk" sedimen (padatan) ke dalam larutan. Beberapa faktor yang berpengaruh adalah waktu kontak, konsentrasi pelarut, konsentrasi zat terlarut dalam sedimen, spesiasi zat terlarut, kandungan organik /anorganik dalam sedimen dan salinitas.

Pada penelitian ini campuran pelarut asam $\mathrm{HNO}_{3}, \mathrm{HCL}$, dan $\mathrm{HF}$ digunakan pada proses ekstraksi padatcair sehingga terjadi proses desorpsi (pelepasan) logam dari padatan ke bentuk cair. Dengan demikian tujuan penelitian ini adalah untuk mengetahui seberapa besar desorpsi (pelepasan) logam setelah dilakukan ekstraksi secara padat cair menggunakan campuran pelarut asam.

\section{METODOLOGI}

\section{Bahan}

Cuplikan sedimen sungai dari pengambilan di semenanjung Muria pada musim penghujan tanggal 22 April 2007 sampai 25 April 2007, akuabides, $\mathrm{HNO}_{3} 65 \%$, HF $40 \%$, $\mathrm{HCl}$ 40\% masing-masing buatan Merck, larutan standar $\mathrm{Cu}, \mathrm{Cr}$ dan Fe nitrat konsentrasi $1000 \mathrm{mg} / \mathrm{l}$ masing-masing buatan BDH, Standard refererence material (SRM) river sediment GBW 1645, dan SRM marine sediment GBW 07313 masing-masing buatan IAEA. akuabides buatan lab kimia analitik PTAPB.

\section{Alat}

Pada penelitian ini digunakan satu perangkat alat atomic absorption spectrometry (AAS) tipe AA-300-P buatan Varian Techtron Australia, teflon bom digester, gelas teflon $50 \mathrm{ml}$, labu ukur $10 \mathrm{ml}$, vial polietilen ukuran 5 $\mathrm{ml}$, mikro pipet effendorf 10 - $100 \mu \mathrm{l}, 250-1000 \mu \mathrm{l}$, dan neraca analitik.

\section{Lokasi Pengambilan Cuplikan}

Cuplikan yang diambil berupa sedimen sungai dengan radius $2 \mathrm{~km}$ hingga $5 \mathrm{~km}$ dari calon tempat dibangunnya PLTN di semenanjung Muria. Lokasi pengambilan cuplikan diantaranya yaitu Sungai Kancilan, Sungai Balong, Sungai Suru, Sungai Dombang, dan Sungai Wareng. Parameter insitu di lokasi adalah suhu, letak bujur timur dan lintang selatan, debit serta kecepatan arus air. Lokasi dan letak astronomis pengambilan sampel seperti dapat dilihat pada Table 1 sebagai berikut : 
Tabel 1. Lokasi dan letak astronomis pengambilan cuplikan

\begin{tabular}{|c|l|c|c|}
\hline No. & \multicolumn{1}{|c|}{ Lokasi } & Bujur Timur & Lintang Selatan \\
\hline 1 & Sungai Kancilan & $110^{\circ}, 46^{\prime}, 40,3^{\prime \prime}$ & $06^{\circ}, 30^{\prime}, 04,5^{\prime \prime}$ \\
2 & Sungai Balong & $110^{\circ}, 47^{\prime}, 47,5^{\prime \prime}$ & $06^{\circ}, 28^{\prime}, 04,8^{\prime \prime}$ \\
3 & Sungai Suru & $110^{\circ}, 48^{\prime}, 48,5^{\prime \prime}$ & $06^{\circ}, 26^{\prime}, 43,5^{\prime \prime}$ \\
4 & Sungai Dombang & $110^{\circ}, 49^{\prime}, 43,1^{\prime \prime}$ & $06^{\circ}, 28^{\prime}, 57,8^{\prime \prime}$ \\
5 & Sungai Wareng & $110^{\circ}, 50^{\prime}, 14,7^{\prime \prime}$ & $06^{\circ}, 27^{\prime}, 48,6^{\prime \prime}$ \\
\hline
\end{tabular}

\section{Preparasi awal cuplikan sedimen}

Cuplikan sedimen hasil sampling dibersihkan dari kotoran seperti batu, rumput dan tumbuhan, kemudian dikeringkan pada suhu kamar, hasil pengeringan digerus menggunakan agat, diayak hingga lolos 100 mesh, dihomoginkan dan ditempatkan wadah polietilen dan diberi label.

\section{Pelarutan cuplikan menggunakan pelarut $\mathrm{HF}, \mathrm{HNO}_{3}$, dan $\mathrm{HCl}$}

Cuplikan sedimen yang telah homogin ditimbang dengan berat $\pm 0,1 \mathrm{~g}$ dalam tabung teflon, dibasahi dengan akuabides dan ditambahkan pelarut dengan variasi campuran pelarut $\mathrm{HNO}_{3} 65 \%+\mathrm{HF} 40 \% ; \mathrm{HNO}_{3} 4 \mathrm{~N}$ $+\mathrm{HCl} 0,7 \mathrm{~N}$ dan $\mathrm{HCl} 0,5 \mathrm{~N}$. Masing-masing tabung teflon dimasukkan ke dalam tabung yang terbuat dari besi, ditutup rapat dan dimasukkan ke dalam tungku pemanas dan dipanaskan pada suhu $150^{\circ} \mathrm{C}$ selama 4 jam. Hasil peleburan setelah dingin dituang ke dalam beker teflon dan dipanaskan di atas penangas pasir dengan penambahan akuabides secara berulang. Hasil pelarutan setelah dingin ditepatkan menjadi volume tertentu dengan penambahan akuabides.

\section{Uji kepekaan dan presisi alat uji}

Uji kepekaan dan presisi alat uji (SSA) dilakukan dengan membuat 1 buah larutan campuran yang terdiri dari larutan standar $\mathrm{Cu} 1000 \mathrm{ppm}, \mathrm{HNO}_{3} 1 \mathrm{~N}$, dan akuatrides sedemikian rupa sehingga konsentrasi Cu dalam larutan $2 \mathrm{ppm}$, dan konsentrasi $\mathrm{HNO}_{3}$ dalam larutan $0,1 \mathrm{~N}$. Kepekaan alat uji ditentukan dengan mengukur serapan larutan tersebut dengan 3 kali pengukuran, sedangkan presisi alat uji ditentukan dengan menghitung simpangan baku dari pengukuran 6 kali serapan larutan tersebut di atas.

\section{Validasi metode uji}

Validasi metode uji dilakukan dengan cara melakukan analisis unsur dalam SRM river sediment GBW 1645, dan SRM marine sediment GBW 07313 masing-masing buatan IAEA. Analisis unsur dilakukan dengan metode kurva kalibrasi standar yaitu dengan cara mengintrapolasikan serapan cuplikan SRM ke dalam kurva kalibrasi masing-masing unsur, sehingga diperoleh konsentrasi regresi masing-masing unsur. Kadar unsur dalam SRM diperoleh dengan menghitung kembali berdasarkan faktor volume pengenceran dan berat cuplikan. Hasil analisis kadar unsur yang diperoleh kemudian dibandingkan dengan kadar yang ada dalam sertifikat SRM

\section{Analisis unsur dalam cuplikan}

Dibuat 5 buah larutan campuran yang terdiri dari $\mathrm{Fe} 100$ ppm, $\mathrm{Cr} 100$ ppm, $\mathrm{HNO}_{3} 1 \mathrm{~N}$ dan akuatrides sedemikian rupa sehingga konsentrasi $\mathrm{HNO}_{3}$ dalam masing-masing larutan campuran tetap $0,1 \mathrm{~N}$, sedangkan konsentrasi Fe dan $\mathrm{Cr}$ dalam larutan campuran bervariasi 0,5; 1,0; 1,5; 2,0; 2,5 ppm. Masing-masing larutan campuran diukur serapannya pada kondisi analisis yang optimum. Analisis unsur $\mathrm{Cu}$ dilakukan dengan cara kerja yang sama dengan variasi konsentrasi $\mathrm{Cu} 0,1 ; 0,2 ; 0,3 ; 0,4$; dan 0,5 ppm. Kadar unsur $\mathrm{Fe}, \mathrm{Cr}$ dan $\mathrm{Cu}$ dalam cuplikan ditentukan dengan cara mengintrapolasikan serapan cuplikan pada kurva standar campuran, konsentrasi yang diperoleh dihitung kembali dengan faktor pengenceran.

\section{HASIL DAN PEMBAHASAN}

Parameter yang berpengaruh pada proses desorpsi logam $\mathrm{Cr}$, $\mathrm{Fe}$, dan $\mathrm{Cu}$ dalam sedimen antara lain adalah suhu, ukuran butiran sedimen, konsentrasi asam yang digunakan dan waktu kontak. Pengaruh suhu terhadap proses desorpsi adalah dengan bertambahnya suhu reaksi, maka kelarutan akan meningkat, sehingga 
proses desorpsi semakin cepat. Demikian juga pengaruh waktu kontak dan ukuran butiran, semakin lama waktu kontak dan semakin kecil ukuran butiran akan memperluas permukaan sehingga proses desorpsi yang terjadi semakin cepat.

Untuk mengetahui keberhasilan proses desorpsi logam $\mathrm{Cr}$, $\mathrm{Fe}$, dan $\mathrm{Cu}$ dalam sedimen, diperlukan metode analisis yang handal baik dalam hal kepekaan maupun validitas metode uji yang digunakan. Salah satu metode analisis yang dapat digunakan adalah metode nyala spektrometri serapan atom. Kepekaan alat uji SSA diperoleh dengan mengukur larutan standar $\mathrm{Cu} 2 \mathrm{ppm}$ sebanyak 3 kali pengukuran. Hasil rerata pengukuran digunakan untuk menghitung kepekaan dengan formula $S=0,0044\left(C_{1} / A_{1}\right)$, dengan $C_{1}$ adalah konsentrasi $C u 2$ $\mathrm{ppm}, \mathrm{A}_{1}$ adalah nilai rata-rata serapan $\mathrm{Cu} 2 \mathrm{ppm}$. Presisi alat uji SSA dilakukan dengan cara kerja yang sama seperti pada penentuan kepekaan dengan pengukuran serapan sebanyak 6 kali pengukuran, kemudian presisi dihitung dengan formula $s=(A-B) \times 0,40$ dengan $A$ adalah nilai serapan tertinggi, dan $B$ adalah serapan terendah ${ }^{(5)}$.

Berdasarkan perhitungan harga kepekaan dan presisi yang disajikan dalam Tabel 2, dapat dikatakan bahwa alat uji SSA masih layak digunakan sebagai alat uji dengan perolehan kepekaan dan presisi yang masih berada di bawah batas yang dipersyaratkan.

Tabel 2. Kalibrasi alat uji SSA metode nyala

\begin{tabular}{|c|l|c|c|}
\hline No. & Parameter & Cu 2 ppm & ASTM $^{(5)}$ \\
\hline 1. & Kepekaan (ppm) & 0,024 & 0,040 \\
2. & Presisi (\%) & 0,74 & 1,0 \\
\hline
\end{tabular}

Validitas metode uji dilakukan dengan cara melakukan analisis unsur dalam SRM river sediment GBW 1645 dan SRM marine sediment GBW 07313 masing-masing buatan IAEA. Hasil analisis unsur dalam SRM dibandingkan dengan data sertifikat SRM. Metode uji dikatakan mempunyai nilai akurasi yang baik bila akurasi yang diperoleh berkisar antara $90-110 \%$, dengan perolehan presisi $<5 \%{ }^{(6)}$.

Nilai akurasi metode uji dihitung menggunakan rumus perhitungan sebagai berikut :

$$
\text { Akurasi }=\frac{\mathrm{HA}}{\mathrm{KS}} \times 100 \%
$$

KS : kadar unsur dalam sertifikat SRM, dan HA : kadar hasil analisis.

Presisi menunjukkan kesesuaian antara beberapa pengulangan yang diukur dengan cara yang sama dan biasanya dinyatakan dalam bentuk nilai relative standard deviation (RSD), dihitung berdasarkan rumus perhitungan :

$$
\text { Presisi }=\frac{s}{\bar{x}} \times 100 \% \text { dengan } s=\sqrt{\sum_{i=1} \frac{(x-\bar{x})^{2}}{(n-1)}}
$$

$\mathrm{s}$ : simpangan, $\mathrm{x}$ : hasil uji, $\mathrm{x}$ : rerata hasil uji, $\mathrm{n}$ : jumlah pengulangan

Pada Tabel 3 disajikan data validitas metode uji berupa nilai akurasi dan presisi menggunakan SRM river sediment GBW 1645, dan SRM marine sediment GBW 07313 masing-masing buatan IAEA.

Tabel 3. Validasi metode uji dengan SRM.

\begin{tabular}{|c|l|l|l|l|l|}
\hline No. & \multicolumn{1}{|c|}{ SRM } & $\begin{array}{c}\text { Kadar hasil analisis } \\
(\mathrm{mg} / \mathrm{g})\end{array}$ & \multicolumn{1}{|c|}{$\begin{array}{c}\text { Kadar dalam sertifikat } \\
(\mathrm{mg} / \mathrm{g})^{(7)}\end{array}$} & Akurasi (\%) & Presisi(\%) \\
\hline 1. & GBW1645 & & & & \\
& $\mathrm{Cr}$ & $29,450 \pm 0,72$ & 29,60 & 99,49 & 2,44 \\
& $\mathrm{Cu}$ & $0,111 \pm 0,002$ & 0,109 & 101,83 & 1,89 \\
& $\mathrm{Fe}$ & $71,24 \pm 0,96$ & 113 & 63,04 & 1,35 \\
\hline
\end{tabular}




\begin{tabular}{|c|l|l|l|l|l|}
\hline No. & \multicolumn{1}{|c|}{ SRM } & $\begin{array}{c}\text { Kadar hasil analisis } \\
(\mathrm{mg} / \mathrm{g})\end{array}$ & $\begin{array}{c}\text { Kadar dalam sertifikat } \\
(\mathrm{mg} / \mathrm{g})^{(7)}\end{array}$ & Akurasi (\%) & Presisi(\%) \\
\hline 2. & GBW 07313 & & & & \\
& Cr & $\left.60,04 \pm 0,96^{*}\right)$ & $\left.58,40^{*}\right)$ & 102,81 & 1,59 \\
& Cu & $0,448 \pm 0,002$ & 0,424 & 101,36 & 0,45 \\
& Fe & $48,01 \pm 0,96$ & 46,02 & 104,32 & 1,99 \\
\hline
\end{tabular}

Berdasarkan pada Tabel 3, validasi metode menggunakan SRM GBW 165 diperoleh akurasi dan presisi untuk logam $\mathrm{Cr}$, dan $\mathrm{Cu}$ memenuhi persyaratan, sedangkan untuk logam $\mathrm{Fe}$ diperoleh akurasi di bawah persyaratan dengan presisi memenuhi persyaratan. Validasi metode uji menggunakan SRM GBW 07313 diperoleh akurasi dan presisi yang memenuhi persyaratan, hal tersebut menunjukkan metode uji yang digunakan adalah valid.

Pengaruh pelarut asam terhadap proses desorpsi logam $\mathrm{Cr}$, $\mathrm{Fe}$, dan $\mathrm{Cu}$ dalam sedimen, ditunjukkan pada Gambar 1, 2, dan 3 sebagai berikut :

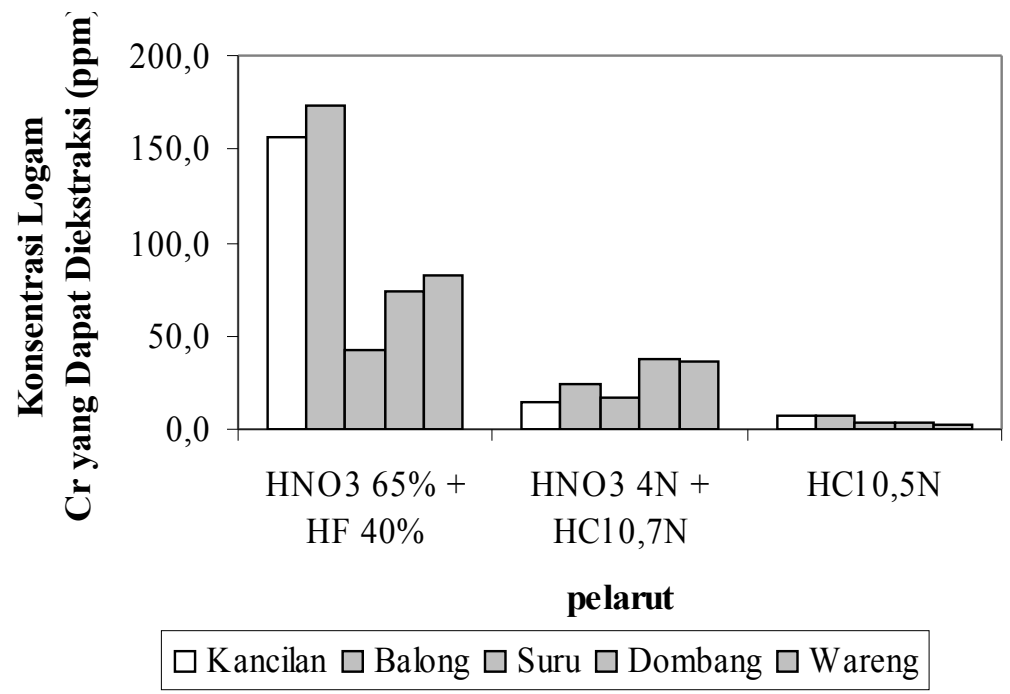

Gambar 1. Kurva hubungan antara desorpsi logam $\mathrm{Cr}$ (ppm) versus pelarut asam

Pada Gambar 1, disajikan proses desorpsi logam $\mathrm{Cr}$ dalam sedimen Sungai Kancilan, Balong, Suru, Dombang, dan Wareng menggunakan 3 (tiga) macam campuran pelarut asam masing-masing $\mathrm{HF}+\mathrm{HNO}_{3}$; $\mathrm{HNO}_{3} 4 \mathrm{~N}+\mathrm{HCl} 0,7 \mathrm{~N}$, dan $\mathrm{HCl} 0,5 \mathrm{~N}$. Berdasarkan pada Gambar 1 proses desorpsi logam $\mathrm{Cr}$ dalam 5 (lima) macam sedimen masing-masing yang terbaik adalah menggunakan campuran pelarut asam $\mathrm{HF} 40 \%+\mathrm{HNO}_{3}$ $65 \%$ dibandingkan dengan 2 pelarut lainnya. Hal tersebut sesuai dengan pendapat Sun Y.C ${ }^{(8)}$ yang menyatakan bahwa asam nitrat dan asam khlorida mempunyai kemampuan yang tinggi untuk melarutkan senyawa organik tetapi kurang baik untuk melarutkan senyawa anorganik (silika) yang terdapat dalam sedimen sungai, sedangkan asam fluorida (HF) merupakan pelarut yang dapat melarutkan senyawa-senyawa silika yang terdapat di dalam sedimen sungai sesuai reaksi sebagai berikut :

$$
6 \mathrm{HF}+\mathrm{SiO}_{2} \rightarrow \mathrm{H}_{2} \mathrm{SiF}_{6}+2 \mathrm{H}_{2} \mathrm{O}
$$

Berdasarkan hasil penelitian yang dilakukan, menunjukkan logam $\mathrm{Cr}$ yang terdesorpsi menggunakan campuran pelarut asam $\mathrm{HF} 40 \%+\mathrm{HNO}_{3} 65 \%$ menghasilkan konsentrasi $\mathrm{Cr}$ tertinggi pada sedimen Balong dengan konsentrasi 173,564 ppm, dan $\mathrm{Cr}$ terendah pada sedimen Suru dengan konsentrasi sebesar 42,970 ppm. Sedangkan apabila menggunakan campuran pelarut asam $\mathrm{HNO}_{3} 4 \mathrm{~N}+\mathrm{HCl} 0,7 \mathrm{~N}$ menghasilkan konsentrasi Cr tertinggi pada sedimen Dombang sebesar 38,02 ppm, dan $\mathrm{Cr}$ terendah pada sedimen Kancilan sebesar 14,95 ppm. Proses desorpsi logam $\mathrm{Cr}$ menggunakan pelarut asam $\mathrm{HCl} 0,5 \mathrm{~N}$ menghasilkan konsentrasi $\mathrm{Cr}$ tertinggi pada sedimen Kancilan sebesar 7,43 ppm dan Cr terendah pada sedimen Wareng sebesar 2,67 ppm. 
Proses desorpsi logam Cu dalam 5 (lima) macam sedimen masing-masing sedimen Sungai Kancilan, Balong, Suru, Dombang, dan Wareng menggunakan 3 (tiga) macam pelarut asam $\mathrm{HF}+\mathrm{HNO}_{3} ; \mathrm{HNO}_{3} 4 \mathrm{~N}+\mathrm{HCl}$ $0,7 \mathrm{~N}$, dan $\mathrm{HCl} 0,5 \mathrm{~N}$ ditunjukkan pada Gambar 2 sebagai berikut :

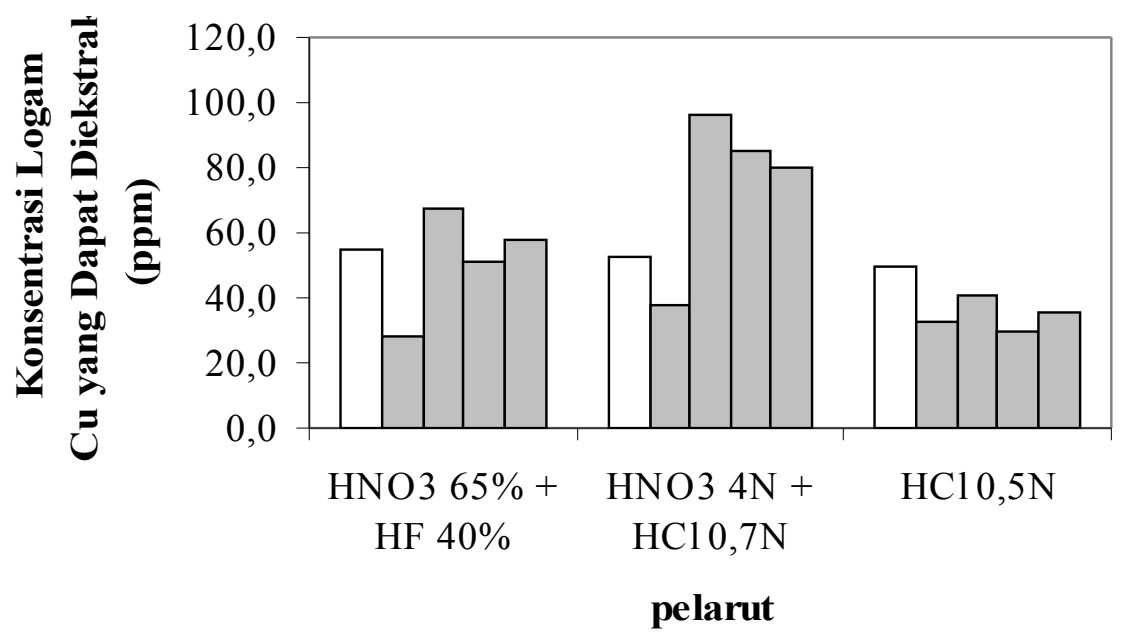

$\square$ Kancilan $\square$ Balong $\square$ Suru $\square$ Dombang $\square$ Wareng

Gambar 2. Kurva hubungan antara desorpsi logam $\mathrm{Cu}(\mathrm{ppm})$ versus pelarut asam

Berdasarkan pada Gambar 2, dapat dikatakan bahwa proses desorpsi logam Cu dalam 5 (lima) macam sedimen masing-masing yang terbaik adalah menggunakan campuran pelarut asam $\mathrm{HNO}_{3} 4 \mathrm{~N}+\mathrm{HCl} 0,7 \mathrm{~N}$, dibandingkan menggunakan campuran pelarut $\mathrm{HF}+\mathrm{HNO}_{3}$ maupun $\mathrm{HCl} 0,5 \mathrm{~N}$. Hal ini dapat terjadi dikarenakan campuran asam $\mathrm{HNO}_{3} 4 \mathrm{~N}+\mathrm{HCl} 0,7 \mathrm{~N}$ dapat melarutkan senyawa organik yang terdapat dalam sedimen sungai, sedangkan menurut Sun Y.C. ${ }^{(8)}$ logam $\mathrm{Cu}$ cenderung tidak berikatan dengan senyawa anorganik (silika) yang terdapat dalam sedimen sungai. Berdasarkan hasil penelitian menunjukkan proses desorpsi logam $\mathrm{Cu}$ menggunakan campuran pelarut asam $\mathrm{HNO}_{3} 4 \mathrm{~N}+\mathrm{HCl} 0,7 \mathrm{~N}$ menghasilkan konsentrasi $\mathrm{Cu}$ tertinggi pada sedimen Suru sebesar 96,24 ppm dan terendah pada sedimen Balong sebesar 37,53 ppm. Sedangkan apabila menggunakan campuran pelarut asam $\mathrm{HF} 40 \%+\mathrm{HNO}_{3} 65 \%$ menghasilkan konsentrasi $\mathrm{Cu}$ tertinggi pada sedimen Suru sebesar 67,23 ppm dan terendah pada sedimen Balong sebesar 27,82 ppm. Proses desorpsi logam $\mathrm{Cu}$ menggunakan pelarut asam $\mathrm{HCl} 0,5 \mathrm{~N}$ menghasilkan konsentrasi $\mathrm{Cu}$ tertinggi pada sedimen Kancilan sebesar 49,31 ppm dan terendah pada sedimen Dombang sebesar 29,70 ppm.

Proses desorpsi logam Fe dalam 5 (lima) macam sedimen masing-masing sedimen Sungai Kancilan, Balong, Suru, Dombang, dan Wareng menggunakan 3 (tiga) macam pelarut asam $\mathrm{HF}+\mathrm{HNO}_{3} ; \mathrm{HNO}_{3} 4 \mathrm{~N}+\mathrm{HCl}$ $0,7 \mathrm{~N}$, dan $\mathrm{HCl} 0,5 \mathrm{~N}$. ditunjukkan pada Gambar 3 sebagai berikut :

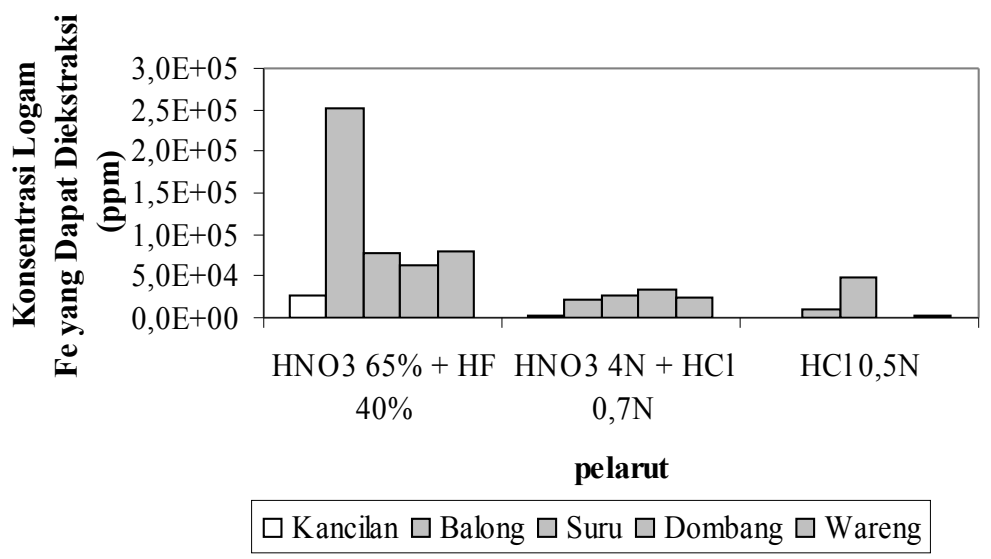

Gambar 3. Kurva hubungan antara desorpsi logam Fe (ppm) versus pelarut 
Berdasarkan pada Gambar 3, dapat dikatakan bahwa penggunaan campuran pelarut $\mathrm{HF} 40 \%+\mathrm{HNO}_{3} 65 \%$ adalah yang terbaik pada proses desorpsi logam $\mathrm{Fe}$ dibandingkan penggunaan campuran pelarut $\mathrm{HNO}_{3} 4 \mathrm{~N}+$ $\mathrm{HCl} 0,7 \mathrm{~N}$, dan $\mathrm{HCl} 0,5 \mathrm{~N}$.. Hal ini dapat terjadi sesuai dengan pendapat Sun Y.C. ${ }^{(8)}$ yang menyatakan bahwa logam $\mathrm{Cr}$, dan $\mathrm{Fe}$ dalam sedimen cenderung berikatan dengan senyawa anorganik (silika), sehingga dengan adanya $\mathrm{HF}$ baik $\mathrm{Cr}$ maupun $\mathrm{Fe}$ dapat terdesorpsi.

Penggunaan campuran pelarut $\mathrm{HF} 40 \%+\mathrm{HNO}_{3} 65 \%$ menghasilkan logam $\mathrm{Fe}$ yang terdesorpsi tertinggi terdapat pada sedimen sungai Balong sebesar 254400,00 ppm dan terendah pada sedimen sungai Dombang sebesar $61782,18 \mathrm{ppm}$. Penggunaan campuran pelarut $\mathrm{HNO}_{3} 4,0 \mathrm{~N}+\mathrm{HCl} 0,7 \mathrm{~N}$ menghasilkan logam Fe yang terdesorpsi tertinggi pada sedimen sungai Dombang sebesar 34554,46 ppm dan terendah terdapat pada sedimen sungai Kancilan sebesar 1745,00 ppm. Penggunaan campuran pelarut $\mathrm{HCl}$ 0,5N menghasilkan logam Fe yang terdesorpsi tertinggi pada sedimen sungai Suru sebesar 49455,45 ppm dan terendah terdapat pada sedimen sungai Balong sebesar 1130,00 ppm.

Beberapa ikatan kimia antara logam yang terdapat di dalam sedimen sungai (baik yang terdapat di dalam senyawa organik, maupun senyawa anorganik) dengan larutan asam yang dimungkinkan terjadi selama proses ekstraksi adalah sebagai berikut ${ }^{(9)}$ :

a. Senyawa organik

- Permukaan luar $\left(\equiv \mathrm{S}-\mathrm{OH}_{2}\right)^{+} \ldots \mathrm{NO}_{3}^{-} \rightarrow\left(\mathrm{ES}-\mathrm{OH}_{2}\right)^{+}+\mathrm{NO}_{3}^{-}$ $\left(\equiv \mathrm{S}-\mathrm{OH}_{2}\right)^{+} \ldots \mathrm{Cl}^{-} \rightarrow\left(\equiv \mathrm{S}-\mathrm{OH}_{2}\right)^{+}+\mathrm{Cl}^{-}$

- Permukaan dalam $(\equiv \mathrm{S}-\mathrm{F})+\mathrm{OH}^{-} \rightarrow(\mathrm{ESOH})+\mathrm{F}^{-}$

b. Senyawa anorganik

- Permukaan luar $(\equiv \mathrm{SOL})+\mathrm{NO}_{3}^{-} \rightarrow(\equiv \mathrm{SO})^{-}+\mathrm{LNO}_{3}$

- Permukaan dalam $(\equiv \mathrm{SOL})+\mathrm{F}^{-} \rightarrow\left(\right.$ (ESO) $+\mathrm{LF}^{-}$

di mana $\equiv S$ : gugus aktif organik yang terdapat di dalam sedimen sungai

$\mathrm{H}_{2} \mathrm{O}, \mathrm{OH}^{-}$: gugus aktif organik yang terdapat di dalam sedimen sungai

$L:$ logam

Berdasarkan hasil penelitian, penggunaan tiga macam pelarut pada proses desorpsi dapat dilihat bahwa konsentrasi logam $\mathrm{Cu}$ yang terdesorpsi relatif tidak berbeda antara ketiga macam pelarut, berbeda dibandingkan dengan logam $\mathrm{Cr}$ dan $\mathrm{Fe}$. Hal tersebut dapat terjadi dikarenakan logam $\mathrm{Cu}$ cenderung tidak berikatan dengan senyawa-senyawa silika yang terdapat di dalam sedimen sungai, berbeda dengan logam $\mathrm{Cr}$ dan $\mathrm{Fe}$ yang banyak berikatan dengan senyawa-senyawa silika yang terdapat di dalam sedimen sungai. Oleh karena itu, logam $\mathrm{Cr}$ dan Fe dapat lebih terdesorpsi dengan adanya pelarut HF yang dapat lebih mudah melarutkan senyawa silika dibandingkan dengan pelarut $\mathrm{HCl}$.

\section{KESIMPULAN}

1. Pada proses desorpsi logam $\mathrm{Cr}$ dan Fe dalam lima macam sedimen sungai (Kancilan, Balong, Suru, Dombang, dan Wareng) yang terbaik adalah menggunakan campuran pelarut asam $\mathrm{HF} 40 \%+\mathrm{HNO}_{3} 65 \%$, dengan kadar $\mathrm{Cr}$ dan Fe yang terdesorpsi 173,56 ppm dan 2544001,00 ppm masing-masing pada sedimen sungai Balong.

2. Pada proses desorpsi logam $\mathrm{Cu}$ dalam lima macam sedimen sungai yang terbaik adalah menggunakan campuran pelarut asam $\mathrm{HNO}_{3} 4,0 \mathrm{~N}+\mathrm{HCl}$ 0,7 dengan kadar $\mathrm{Cu}$ yang terdesorpsi 96,24 ppm pada sedimen sungai Suru.

\section{DAFTAR PUSTAKA}

1. ANONIM, Guidance for Environmental Background Analysis., vol.II.sediment., NFECS user guide UG-2054ENV., Naval Facilities Engineering Command., Washington DC 20374-5065, 2003.

2. ZIWART.D., AND TRIVEDI.R.C., Manual on intergrated water quality evaluation., report 802023003 , Biomonitoring Indian River II., RIVM proyect 754192 IN/92/021, 1994. 
3. CANTER.L.W., "Environmental Impact Assessment"., McGraw-Hill, Inc., New York, 1996.

4. MURRAY.C.N, AND MURRAY. L.,"Adsorption-desorption aquilibria of some radionuclides in sedimen-freshwater and sedimen-seawater systems", Proceeding of a symposium seattle, 10 - 14 Juli 1972.

5. ASTM E 663-86 (Reapproved 1991), Standard Practice For Flame Atomic Absorption Analysis, American Nasional Standard, Philadelphia, 1991.

6. SUMARDI, Validasi Metode Analisis, Bahan Kuliah Pelatihan Asesor Laboratorium, Badan Standardisasi Nasional, BSN, Jakarta, Oktober 2001.

7. ANONIM, International Atomic Energy Agency, Certificate Reference Materials Marine Sediment GBW07313, IAEA, Vienna,1995.

8. SUN.Y,C., CHI.P.C., and SHIEU.M.Y., Comparison of different Digestion Methods for total Decomposition of Siliceous and Organic Environmentals Sample, Analytical Sciences December 2001, Vol. 17, p. $1395-1399$.

9. WU et.al., 1996 dalam Ming Chen and Lena Q. Ma.," Comparation of three aqua regia methods for twenty florida soils", Soil Sci.Soc.Am.J., 2001, p. 491. 